\title{
Ethical Content of Expert Recommendations for End-of-Life Decision-Making in Intensive Care Units: a Systematic Review
}

AUTHORS:

Diana Spoljar (Špoljar) $)^{a^{*}}$

Marko Curkovic (Ćurković) ${ }^{\mathrm{b}}$

Chris Gastmans ${ }^{\mathrm{c}}$

Bert Gordijn $^{\mathrm{d}}$

Dina Vrkic $(\text { Vrkić) })^{\mathrm{e}}$

Ana Jozepovic (Jozepović) $)^{\mathrm{f}}$

Suzana Vuletic (Vuletić) ${ }^{g}$

Dinko Tonkovic (Tonković) ${ }^{\mathrm{h}}$

Ana Borovecki (Borovečki) ${ }^{\mathrm{i}}$

${ }^{a}$ University Hospital Dubrava, School of Medicine, University of Zagreb

Avenija Gojka Ššska 6, 10000 Zagreb, Croatia

dianaspoljar@gmail.com

${ }^{b}$ University Psychiatric Hospital Vrapče, School of Medicine, University of Zagreb

Bolnička Cesta 32, 10000 Zagreb, Croatia

markocurak@gmail.com

${ }^{c}$ Centre for Biomedical Ethics and Law, Faculty of Medicine, KU Leuven

Kapucijnenvoer 35 Box 7001, 3000 Leuven, Belgium

chris.gastmans@kuleuven.be

${ }^{d}$ Institute of Ethics, School of Theology, Philosophy, and Music, Dublin City University DCU All Hallows Campus, Dublin 9, Ireland

bert.gordijn@dcu.ie

${ }^{e}$ Central Medical Library, School of Medicine, University of Zagreb

Šalata ul. 2, 10000 Zagreb, Croatia

dina.vrkic@mef.hr

${ }^{f}$ School of Medicine, University of Zagreb

Šalata ul. 2, 10000 Zagreb, Croatia

ana.jozepovic@gmail.com

${ }^{g}$ Catholic Faculty of Theology in Đakovo, University of Josip Juraj Strossmayer in Osijek

Petra Preradovića 17, 31400 Đakovo, Croatia

suzanavuletic007@gmail.com

${ }^{h}$ University Hospital Centre Zagreb, School of Medicine, University of Zagreb,

Kišpatićeva ul. 12, 10000 Zagreb, Croatia

dtonkovic@yahoo.com

${ }^{i}$ Andrija Stampar School of Public Health, School of Medicine, University of Zagreb Johna Davidsona Rockfellera 4, 10000 Zagreb, Croatia

aborovec@gmail.com

*Corresponding author:

Diana Špoljar

Mobile: +385 915405727

E-mail: dianaspoljar@gmail.com

Postal address: Avenija Gojka Šuška 6, 10000 Zagreb, Croatia 


\section{ABSTRACT}

Purpose: Intensive care unit health care professionals must be skilled in providing end-of-life care. Crucial in this kind of care is end-of-life decision-making, which is a complex process involving a variety of stakeholders and requiring adequate justification. The aim of this systematic review is to analyse papers tackling ethical issues in relation to end-of-life decision-making in intensive care units. It explores the ethical positions, arguments and principles.

Methods: A literature search was conducted in bibliographic databases and grey literature sources for the time period from 1990 to 2019. The constant comparative method was used for qualitative analysis of included papers in order to identify ethical content including ethical positions, ethical arguments, and ethical principles used in decision-making process.

Results: In the 15 included papers we have identified a total of 43 ethical positions. Ten positions were identified as substantive, 33 as procedural. Twelve different ethical principles emerged from the ethical arguments. The most frequently used principles are the principles of beneficence, autonomy and nonmaleficence.

Conclusions: We have demonstrated that recommendations and guidelines designed specifically by intensive or critical care experts for intensive care units promote similar ethical positions, with minimal dissenting positions.

Key words: intensive care units, end-of-life care, end-of-life decision-making, ethics 


\section{Introduction:}

Intensive care units (ICUs) are very specific as they provide patients with the most advanced treatments which can sustain life despite severe illness. However, ICUs are also a setting where patients approach the end of their lives, and death is common [1,2]. ICU health care professionals must therefore be skilled in providing endof-life care. Crucial in this kind of care is end-of-life decision-making, which is a complex process involving a variety of stakeholders and requiring adequate justification, while keeping the patient's best interests in mind [3]. A substantial variability in providing end-of-life care has been found between world regions, countries, even individual ICUs within a country [4]. Carefully designed protocols and guidelines can improve the quality of endof-life care in the ICU $[1,4,5]$.

Health care professionals working in ICU are often under pressure to make swift decisions and act accordingly in the context of multifaceted uncertainty. Any action or inaction can have important medical and ethical repercussions. General end-of-life guidelines can sometimes be inapplicable in said circumstances. Therefore, there is a need for recommendations and guidelines designed specifically by intensive or critical care experts for ICUs.

The aim of this systematic review is to analyse papers tackling ethical issues in relation to end-of-life decision-making in ICUs. It explores the ethical positions, the ethical arguments supporting these positions, and the ethical principles underlying these arguments.

\section{Methods}

This systematic review was conducted and is reported in accordance with the Preferred Reporting Items for Systematic reviews and Meta-Analyses (PRISMA) guidelines [6].

\section{$\underline{\text { 2.1. Search strategy }}$}

A literature search was conducted in February 2018 and updated in September 2019 in bibliographic databases and grey literature sources for the time period from 1990 to 2019 . The year of 1990 was set as a limit because in that year the World Health Organization issued a report of an expert committee describing the concept of palliative care [7].

We included bibliographic databases (Ovid MEDLINE, PubMed, Ebsco CINAHL and EBSCO PsycINFO), and grey literature sources: repositories (ProQuest Dissertations \& Theses Global (PQDT), DART 
Europe E-theses Portal, EThOS, Networked Digital Library of Theses and Dissertations (NDLTD), OpenThesis, OpenAIRE, OpenGrey.eu), social network sites (CiteULike, Mendeley), and Google Scholar search engine. In the second search, we excluded CiteULike due to the shutdown of service from March 30th, 2019. Search strategies in bibliographic databases were conducted using MeSH terms and keywords related to "end of life", "palliative care" and "intensive care unit" terms. See Appendix for details of search strategy and strings used.

Grey literature is usually understood as literature that is not formally published in sources such as books or journal articles [8]. Some examples are: theses and dissertations, conference papers/proceedings, presentations, newsletters, unpublished or ongoing studies, informal communication, and government documents.

In our grey literature search strategy, we needed to focus on the recurring terms noticed when conducting bibliographic database searches. Therefore, we focused on the commonly known terms such as "end of life", "palliative care", "intensive care unit". Since grey literature sources have limitations regarding the search, we needed to use the most common and core concepts of the search terms.

\subsection{Inclusion / exclusion criteria}

The databases search results were deduplicated and we retrieved 7445 papers. Three researchers conducted the screening process independently. The papers were firstly selected based on the title. They were only included if published as articles in peer reviewed journals in English between 1990 and 2019, and if they dealt with end-of-life decisions in adult ICU. This resulted in 6811 exclusions, leaving 634 papers (see figure 1).

The next step involved reading the abstracts, resulting in 588 further exclusions, thus leaving 46 papers. The papers were only included if they provided positions or recommendations on end-of-life decision-making process in ICU and were developed by health care professional institutions or panels of intensive care experts on a national or transnational level. They were excluded if they dealt with only one method of treatment (i.e. only mechanical ventilation) or referred to a specific disease (i.e. dementia), if they included medical disciplines other than intensive care (i.e. cardiology) in the content, if issued by non-professional organisations or if they were national or transnational professional documents dealing with end-of-life issues on a general level, and not specifically focused on end-of-life decision-making in ICU.

One researcher read the full texts of 46 papers and went through the bibliographies for additional papers (snowballing technique). In case of uncertainty whether a specific paper satisfied the inclusion criteria another researcher was consulted, and a mutual decision was reached. 
This resulted in 15 eligible papers, fourteen of which were detected by reading the full text, and one by scanning the reference list (see table 1). Only papers satisfying all of the inclusion and exclusion criteria were included in the review. Articles identified by snowballing technique were screened by the same criteria.

\subsection{Qualitative analysis}

The constant comparative method was used for qualitative analysis of the 15 included papers in order to identify ethical content including ethical positions, ethical arguments, and ethical principles used in the end-of-life decision-making processes $[9,10]$. By this inductive method we were able to analyse the text by coding, categorizing, and comparing the data [11]. Passages of the text were labelled with an adequate code, which were subsequently compared, refined and categorized. In this process initial codes were changed as necessary, and ethical positions were created. Subsequently, we performed axial coding, i.e. connections between the categories of ethical positions were considered and they were grouped according to their content. It is important to stress that the boundaries between the ethical positions are not always strict as some of them overlap, and a clear distinction cannot be made in some cases. In cases of uncertainty another researcher was consulted, and a mutual decision was reached.

\section{Results}

A total number of 15 papers which met the inclusion criteria - providing statements or recommendations on ICU end-of-life decision-making developed by critical or intensive care societies or experts, have been included for analysis (see table 1). Fourteen papers are country specific, while one is international. Seven are thematically mostly focused on withholding and withdrawing of treatment. Five papers tackle withholding/withdrawing of treatment as well as palliative care and terminal sedation. Two further papers are primarily dealing with palliative care and terminal sedation, and one final paper deals exclusively with intentional life-terminating actions. 
Table 1. List of included papers

\begin{tabular}{|c|c|c|c|c|c|}
\hline & $\begin{array}{l}\text { Publication } \\
\text { year and } \\
\text { reference }\end{array}$ & Country & Issued by & $\begin{array}{c}\text { Dealing with: } \\
\text { Withholding / withdrawing } \\
\text { treatment (WH/WD); } \\
\text { Palliative care and terminal } \\
\text { sedation (PC and TS); } \\
\text { Intentional life-terminating } \\
\text { actions (ILTA) }\end{array}$ & \\
\hline 1 & $1990(22)$ & USA & $\begin{array}{l}\text { Task Force on Ethics of the Society of } \\
\text { Critical Care Medicine }\end{array}$ & WH/WD & \\
\hline 2 & 1990 & USA & $\begin{array}{l}\text { Society of critical care medicine / American } \\
\text { college of chest physicians }\end{array}$ & WH/WD & 13 \\
\hline 3 & 2000 & Canada & Critical care society & WH/WD & 24 \\
\hline 4 & 2001 & USA & $\begin{array}{l}\text { Ethics Committee of the Society of Critical } \\
\text { Care Medicine }\end{array}$ & $\begin{array}{l}\text { WH/WD; } \\
\text { PC and TS }\end{array}$ & 14 \\
\hline 5 & 2002 & Canada & $\begin{array}{c}\text { Critical Care fellowship program directors, } \\
\text { Intensive Care Division Chief, provincial } \\
\text { Deputy Coroners/Medical Examiners, } \\
\text { academic Adult intensivists }\end{array}$ & $\mathrm{PC}$ and TS & 12 \\
\hline 6 & 2003 & Italy & $\begin{array}{c}\text { Italian society of anaesthesia, analgesia, } \\
\text { resuscitation }\end{array}$ & WH/WD & 15 \\
\hline 7 & 2006 & Italy & $\begin{array}{c}\text { Italian society of anaesthesia, analgesia, } \\
\text { resuscitation }\end{array}$ & $\begin{array}{l}\text { WH/WD; } \\
\text { PC and TS }\end{array}$ & 16 \\
\hline 8 & 2008 & Austria & $\begin{array}{c}\text { Austrian Associations of Intensive Care } \\
\text { Medicine }\end{array}$ & WH/WD & 18 \\
\hline 9 & 2008 & USA & $\begin{array}{c}\text { American College of Critical Care } \\
\text { Medicine }\end{array}$ & $\begin{array}{l}\text { WH/WD; } \\
\text { PC and TS }\end{array}$ & 17 \\
\hline 10 & 2012 & India & Indian Society of Critical Care Medicine & $\mathrm{PC}$ and TS & 19 \\
\hline 11 & 2014 & International & Critical care societies worldwide & $\begin{array}{l}\text { WH/WD; } \\
\text { PC and TS }\end{array}$ & 23 \\
\hline 12 & 2014 & India & $\begin{array}{l}\text { Indian society of Critical Care Medicine \& } \\
\text { Indian Association of Palliative Care }\end{array}$ & $\begin{array}{l}\text { WH/WD; } \\
\mathrm{PC} \text { and TS }\end{array}$ & 20 \\
\hline 13 & 2014 & Belgium & Belgian Society of Intensive Care Medicine & ILTA & 26 \\
\hline 14 & 2016 & Canada & Canadian Critical Care Society & WH/WD & 21 \\
\hline 15 & 2018 & Canada & Canadian Critical Care Society & WH/WD & 25 \\
\hline
\end{tabular}

\subsection{Content of the papers}

The ethical content of the papers was analysed by firstly identifying ethical positions from the papers, secondly, by identifying ethical arguments supporting those positions, and finally, by identifying ethical principles used in the end-of-life decision-making processes. 
In this review the term 'ethical position' is used for positions and recommendations which emerged from the qualitative analysis and pertain to the ethical aspect (e.g. patient's rights, wishes and values should be respected), and not to the practical aspect of end-of-life decision-making (e.g. doses of medications used).

Ethical arguments which emerged from the papers supporting an ethical position were noted. They contain an explanation and a reasoning why a certain ethical position should be followed (e.g. the principle of autonomy grants patients with decision-making capacity the right to refuse any and all therapies, therefore patient's rights, wishes and values should be respected).

Some ethical positions are not supported by clearly expressed ethical arguments. Those ethical positions are either mentioned in the papers as a supporting statement, without a justification in form of an ethical argument (e.g. patient's desire, expressed in writing or verbally, must be held in highest consideration), or, for some ethical positions, there is a broader explanation or description pertaining to the ethical aspects of the positions (e.g. patient's wishes should be ascertained from capable patients, or surrogates when the patient is not capable of making decisions).

Ethical principles, such as principle of autonomy, beneficence, etc., were in some cases mentioned in the papers in relation to some ethical positions and arguments, and were, therefore, analysed in this review.

We have identified a total of 43 ethical positions. Ethical arguments were identified for 37 of those positions. In those 37 positions with identified ethical arguments, for only 3 we did not find any additional information or supporting statement. There are 6 positions for which we did not find ethical arguments in any of the papers, however we found either a supporting statement or additional information.

A distinction was made between substantive and procedural positions, and we have decided to analyse them separately. The substantive positions express certain values and offer unambiguous direction (e.g. 'euthanasia is not permissible'), while the procedural positions pertain to hands-on decisions made in everyday practice and decision-making process (e.g. 'patients' capacity should be assessed'). Ten positions were identified as substantive, and the rest of the 33 positions as procedural, as listed in tables 2 and 3, respectively.

\subsection{Substantive positions}

The substantive positions that were drawn from our qualitative analysis and ethical principles are listed in table 2, including the number and references of papers where supporting statements and additional information connected to each position and related ethical arguments are provided. 
The substantive positions were grouped under the 6 categories of medical end-of-life practices as categorised by the Dutch research team: euthanasia, physician-assisted suicide, ending of life without explicit patient request, intensified alleviation of symptoms (taking into account possible hastening of death), forgoing of life-prolonging treatment, and continuous deep sedation [27].

Two substantive positions emerged as the most prominent: patients' pain and suffering should be alleviated, even if it may hasten death, and withholding and withdrawing of treatment are morally equal, and permissible. Both were mentioned in all of the included papers. Other substantive positions mentioned in ten or more papers state that palliative care should be provided to all ICU patients until the end of their lives, and medically futile treatments - that offer no benefit to the patient - should not be offered, maintained or started.

Even though euthanasia and physician-assisted suicide are permitted by law in some countries, only one paper clearly states that medical assistance in dying is decriminalized in specific circumstances [25], while two papers state that physician-assisted suicide is not legal $[19,20]$. Several papers conclude that euthanasia is illegal in certain countries at the time they were published $[17,19,20,24]$. Some of the papers also state that forgoing life-sustaining treatments, palliative care and terminal sedation are not the same as euthanasia $[12,14-17,25]$. Only one of the included papers exclusively supports and discusses the issue of intentional shortening of the dying process by administering sedatives in a larger dose than needed for patient comfort [26]. This paper does not clearly state whether it pertains to patients who have not given their explicit consent, but one can understand from the text that it is describing cases where the patients do not have capacity, nor have they made such requests while capable. Continuous deep sedation, also referred to as terminal or palliative sedation, is mentioned in three papers and merely differentiated from euthanasia $[12,14,16]$.

The substantive positions stating that forgoing life-sustaining treatments, palliative care and terminal sedation are not the same as euthanasia is placed under two different Dutch categories (euthanasia and continuous deep sedation), as it pertains to both.

\section{$\underline{\text { 3.3. Procedural positions }}$}

Since the medical end-of-life practices as categorised by the Dutch research team have only 6 categories, certain positions that were identified in our qualitative analysis could not be classified in those categories. Table 3 shows the list of the procedural positions, which we decided to collect under themes according to their content. Again, we identified supporting statements and additional information connected to each position, ethical arguments, and ethical principles that can be drawn from these ethical arguments. 
The procedural positions relate to the decision-making process. Some are focused on certain stakeholders such as patients, family, surrogates and members of the medical team. Others provide guidance on what to keep in mind during the decision-making process and how to deal with certain issues that may arise. We have distinguished 8 content themes of procedural positions: patient related, family / surrogate related, obligations to patients and families, medical team related, treatment justification, transparency, general principles of the ICU, miscellaneous.

Two procedural positions emerged as the most prominent: effective communication with the patient, family, surrogates and between ICU team is of paramount importance, and good medical records should be kept. Both were mentioned in all of the included papers. Other positions mentioned in ten or more papers state that patients' rights, wishes and values should be respected, shared decision-making model is the preferred way of making end-of-life decisions, psychosocial needs of the patients and families should be met, and disagreements between any of the involved parties should be resolved.

There are no dissenting opinions in the aforementioned positions, except on the resort to institutional ethics committees. Many of the papers support the notion of resorting to institutional ethics committees in order to resolve a disagreement $[13,15-17,19,20,22,23,25]$. However, one paper expresses the opinion that such action is inadvisable [18]. It is argued that committees comprising of individuals who are not in immediate contact with the involved patient and critical care medicine do not possess the required insight and experience to make any substantial contribution to the process. 
Table 2. List of substantive positions with related supporting statements / additional information, ethical arguments and principles

\begin{tabular}{|c|c|c|c|c|}
\hline $\begin{array}{l}\text { CATEGORIES } \\
\text { OF END-OF- } \\
\text { LIFE } \\
\text { PRACTICES }\end{array}$ & $\begin{array}{l}\text { SUBSTANTIVE } \\
\text { POSITIONS }\end{array}$ & $\begin{array}{l}\text { SUPPORTING } \\
\text { STATEMENT / } \\
\text { ADDITIONAL } \\
\text { INFORMATION } \\
\text { (with references) } \\
\end{array}$ & ETHICAL ARGUMENTS (with references) & $\begin{array}{l}\text { ETHICAL } \\
\text { PRINCIPLES (with } \\
\text { references) }\end{array}$ \\
\hline \multirow[t]{2}{*}{ Euthanasia } & $\begin{array}{l}\text { Euthanasia is not } \\
\text { permissible }\end{array}$ & $\begin{array}{l}\text { - Active shortening of } \\
\text { the dying process with } \\
\text { the intention to hasten } \\
\text { death is not permissible } \\
\text { by law, } 17,19,20,24\end{array}$ & & \\
\hline & $\begin{array}{l}\text { Forgoing life-sustaining } \\
\text { treatments, palliative care } \\
\text { and terminal sedation are } \\
\text { not the same as euthanasia }\end{array}$ & & $\begin{array}{l}\text { - doctrine of double effect defines the line between euthanasia and acceptable palliative care, } 17 \\
\text { - terminal sedation (TS) is justified under the rule of double effect when all other methods of } \\
\text { controlling patient's suffering have failed, } 14 \\
\text { - TS is palliative care, not euthanasia, it may arguably make the detection of euthanasia more } \\
\text { difficult, the intent of the physician is crucial, } 12 \\
\text { - there is an important distinction between killing and allowing to die- the withdrawal of life- } \\
\text { sustaining treatments is not legally considered a killing, } 15,17 \\
\text { - terminal sedation / palliative sedation (TS/PS) is strictly differentiated from euthanasia in } \\
\text { purpose and procedure (drugs and doses), as well as in outcome, } 16 \\
\text { - Active shortening of the dying process does not include withdrawing or withholding life- } \\
\text { sustaining treatment, } 23 \\
\text { - withholding / withdrawing life-sustaining treatment (WH/WD LST) is not equivalent to } \\
\text { medically assisted death or euthanasia, } 25\end{array}$ & - double effect, 14,17 \\
\hline $\begin{array}{l}\text { Physician - assisted } \\
\text { suicide }\end{array}$ & $\begin{array}{l}\text { Physician assisted suicide is } \\
\text { not permissible }\end{array}$ & $\begin{array}{l}\text {-physician assisted } \\
\text { suicide is not permissible } \\
\text { by law, } 19,20 \\
\text { - medical assistance in } \\
\text { dying is decriminalized } \\
\text { in specific } \\
\text { circumstances, } 25 \\
\end{array}$ & & \\
\hline $\begin{array}{l}\text { Ending of life } \\
\text { without explicit } \\
\text { patient request }\end{array}$ & $\begin{array}{l}\text { Shortening of the dying } \\
\text { process by administering } \\
\text { sedatives can be desirable } \\
\text { in some cases }\end{array}$ & & $\begin{array}{l}\text { - shortening of the dying process with use of medication even in the absence of discomfort, can } \\
\text { improve the quality of dying, help relatives accompany their loved one through the dying process, } \\
\text { the intention must not be interpreted as killing but as a humane act to accompany the patient at the } \\
\text { end of his life, } 26\end{array}$ & \\
\hline $\begin{array}{l}\text { Intensified } \\
\text { alleviation of } \\
\text { symptoms }\end{array}$ & $\begin{array}{l}\text { Patients' pain and suffering } \\
\text { should be alleviated, even if } \\
\text { it may hasten death }\end{array}$ & $\begin{array}{l}\text { - morally justified to } \\
\text { provide pain relief even } \\
\text { if foreseen that life will } \\
\text { be shortened, } 13\end{array}$ & $\begin{array}{l}\text { - relieving pain in patients whose life-support is being removed ensures death will come with } \\
\text { dignity, } 22 \\
\text { - physicians have an obligation to provide care that relieves suffering, and should administer doses } \\
\text { that are intended to relieve pain but not to directly cause death, } 14,15,16\end{array}$ & $\begin{array}{l}\text { - respect for patient's } \\
\text { dignity, } 22,25 \\
\text { - double effect, } 12 \\
16,17,19,20,25\end{array}$ \\
\hline
\end{tabular}




\begin{tabular}{|c|c|c|c|c|}
\hline \multirow[t]{2}{*}{$\begin{array}{l}\text { (possibly } \\
\text { hastening death) }\end{array}$} & & $\begin{array}{l}\text { - when removing life } \\
\text { sustaining treatment } \\
\text { (LST) pain should be } \\
\text { relieved, even if it } \\
\text { hastens death, 15, 22, } 24 \\
\text { - pharmacological and } \\
\text { non-pharmacological } \\
\text { means should be used, } \\
\text { there is no maximum } \\
\text { dose of narcotics or } \\
\text { sedatives, } 12,21 \\
\text { - goal is to anticipate, } \\
\text { prevent, and relieve } \\
\text { suffering and to optimize } \\
\text { quality of life for patients } \\
\text { with terminal illnesses, } \\
23 \\
\text { - suffering should be } \\
\text { avoided at all times, } 26 \\
\text { - assuring freedom from } \\
\text { pain and maintaining } \\
\text { patient's dignity must be } \\
\text { of primary concern at } \\
\text { every stage of therapy } \\
\text { withdrawal, } 18\end{array}$ & $\begin{array}{l}\text { - principle of double effect states that administration of opioids and sedatives is an appropriate } \\
\text { treatment to control pain, despite the risk of accelerating the course of death, } 16,25 \\
\text { - alleviation of pain is crucial to the provision of quality end-of-life care, intent of the physician } \\
\text { based on the principle of double effect, } 12,17 \text {, } \\
\text { - treatments intended to relieve suffering and not to hasten death may involve actions or omissions } \\
\text { that sometimes hasten the patient's death as an anticipated, but unintended consequence, } 23 \\
\text { - when withholding / withdrawing (WD/WH) life-sustaining modalities physician is ethically } \\
\text { obliged to continue to provide care that alleviates patient's distress, as hastening of death is } \\
\text { unintended, doctrine of double effect distinguishes intended and unforeseen effects, } 19 \\
\text { - freedom from pain is a fundamental right and withholding adequate palliative therapy would } \\
\text { violate the principle of nonmaleficence; doctrine of double effect clearly sets the obligation to } \\
\text { provide freedom from pain above the principle to do no harm provided the harm is unintended, } 20 \\
\text { - when WH/WD LST the ICU team may use opioids and/or sedatives to relieve suffering; } \\
\text { principles of beneficence and non-maleficence refer to actions of relieving pain and suffering, } \\
\text { patient should be provided with respectful and dignified death, } 25\end{array}$ & \begin{tabular}{|l|} 
- professional duty, \\
$14,15,16,19$ \\
- nonmaleficence, 19, \\
20,25 \\
- beneficence, 25
\end{tabular} \\
\hline & $\begin{array}{l}\text { Palliative care should be } \\
\text { provided to all ICU } \\
\text { patients, until the end of } \\
\text { their lives }\end{array}$ & $\begin{array}{l}\text { - withdrawal of care } \\
\text { should never occur, } 15, \\
17,18,26,25 \\
\text { - ensuring good } \\
\text { palliative care in the ICU } \\
\text { is crucial; goals of } \\
\text { palliative care are relief } \\
\text { of pain, psychological } \\
\text { and spiritual support of } \\
\text { patient and family, } \\
\text { provision of comfort, } 12 \\
\text { - physicians and nurses } \\
\text { both should participate in } \\
\text { providing palliative care, } \\
21\end{array}$ & $\begin{array}{l}\text { - all intensive care patients can benefit from inclusion of the principles of palliative care in their } \\
\text { management, } 14 \\
\text { - palliative care throughout the continuum of illness involves addressing various needs, facilitates } \\
\text { patient autonomy - patients are entitled to a dignified death with as little pain and suffering as } \\
\text { possible, } 23 \\
\text { - when the patient is likely to die the prime objective becomes his comfort, which is the objective } \\
\text { of palliative treatments in the ICU, } 16 \\
\text { - It is a professional duty to work toward the administration of palliative treatments which relieve } \\
\text { symptoms of WH/WD treatments and grant the best possible quality of life until the end, } 16 \\
\text { - physician is obliged to provide compassionate and effective palliative care to the patient under } \\
\text { the principle of beneficence, } 19 \\
\text { - withholding adequate palliative therapy would violate principle of nonmaleficence, as freedom } \\
\text { from pain and distress is a fundamental right, } 20 \\
\text { - palliative care services provide additional expertise and support, should be considered in } \\
\text { transition to comfort care, } 25\end{array}$ & $\begin{array}{l}\text {-professional duty, } 16 \\
\text { - beneficence, } 19 \\
\text { - nonmaleficence, } 20 \\
\text { - autonomy, } 23 \\
\text { - respect for patient's } \\
\text { dignity, } 23\end{array}$ \\
\hline
\end{tabular}




\begin{tabular}{|c|c|c|c|c|}
\hline \multirow[t]{4}{*}{$\begin{array}{l}\text { Forgoing of life- } \\
\text { prolonging } \\
\text { treatment }\end{array}$} & $\begin{array}{l}\text { Medically futile treatments } \\
\text { - that offer no benefit to the } \\
\text { patient - should not be } \\
\text { offered, started or } \\
\text { maintained }\end{array}$ & $\begin{array}{l}\text { - physicians have no } \\
\text { obligation to discuss or } \\
\text { provide treatments } \\
\text { deemed physiologically } \\
\text { futile, } 15,22 \\
\text { - ethically desirable to } \\
\text { stop nonbeneficial } \\
\text { treatment and to avoid } \\
\text { continuing futile } \\
\text { treatment, } 26\end{array}$ & $\begin{array}{l}\text {-medically futile treatments cannot achieve the medical goal and need not be discussed with } \\
\text { patients, } 13 \\
\text { - physicians not obliged to provide treatments which are not effective or in accord with medical } \\
\text { standard, } 17,19,20,24,25 \\
\text { - therapy for which no ground can be given is not ethically justified, and can represent bodily } \\
\text { harm if it prolongs irreversible processes, } 18 \\
\text { - all futile life supports should be removed for the sake of patient's comfort, } 16 \\
\text { - physician's insisting on continuation of futile therapies is a violation of principle of beneficence } \\
\text { as it flows from the fiduciary obligation to act always in patient's best interests, } 20 \\
\text {-futile application to therapies violates the principle of social justice which entails allocating } \\
\text { resources appropriate to the medical condition of the patient in order to maximize their benefits } \\
\text { and minimize wastage, } 20 \\
\text { - therapies that solely artificially prolong life should not be started or should be discontinued as } \\
\text { they violate the principle of proportionality of care, } 26 \\
\text { - overtreatment amounts to inappropriate utilisation of resources, produces unfair distribution of } \\
\text { resources, causes harm, doesn't respect dignity in dying, } 15\end{array}$ & $\begin{array}{l}- \text { nonmaleficence, } 15, \\
18 \\
\text { - proportionality of } \\
\text { care, } 26 \\
\text { - social justice, } 15,20 \\
\text { - respect for patient's } \\
\text { dignity } 15 \\
\text { - beneficence, } 20\end{array}$ \\
\hline & $\begin{array}{l}\text { The dying process should } \\
\text { not be prolonged }\end{array}$ & $\begin{array}{l}\text { - dying process should } \\
\text { not be prolonged, } 24 \\
\text { - treatments delaying } \\
\text { death for no good reason } \\
\text { or that are excessive } \\
\text { (disproportionate) should } \\
\text { not be practiced, } 15\end{array}$ & $\begin{array}{l}\text { - It is a professional duty to avoid prolonging the process of death, } 16 \\
\text { - that an irreversible dying process should not be prolonged is in conformity with the norm of a } \\
\text { physician's professional ethics embedded in medical law, namely, the well-being of the patient } \\
\text { must be assured, } 18 \\
\text { - therapy can represent bodily harm if it only prolongs irreversible processes, } 18 \\
\text { - when interventional therapies may only prolong a patient's dying process without offering } \\
\text { benefit to the patient, they should not be used, } 23 \\
\text { - beneficence implies acting in what is in patient's interest - as the physician is expected to act in } \\
\text { the best interests his expanded goals include neither hastening nor delaying the dying process, } 19 \\
\text { - therapies that solely artificially prolong life should not be started or should be discontinued as } \\
\text { they violate the principle of proportionality of care, } 26\end{array}$ & $\begin{array}{l}- \text { beneficence, } 18,19, \\
23 \\
\text {-professional duty, } 16, \\
18 \\
\text { - nonmaleficence, } 18 \\
\text { - proportionality of } \\
\text { care, } 26\end{array}$ \\
\hline & $\begin{array}{l}\text { Withholding and } \\
\text { withdrawing of treatment } \\
\text { are morally equal, and } \\
\text { permissible }\end{array}$ & $\begin{array}{l}\text { - WH / WD of treatment } \\
\text { is permissible, 12-26 } \\
\text {-there is no moral } \\
\text { difference in WH and } \\
\text { WD LST, } 13,15,17,18 \text {, } \\
22,24,26,25\end{array}$ & $\begin{array}{l}\text { - physicians have ethical and medical responsibility to WH/WD treatments in appropriate } \\
\text { situations, } 13 \\
\text {-WH/WD of treatment is permissible when: } \\
\text { - patients judge it is preferable, } 17,22,23 \\
\text { - clinicians judge major goals of treatment are unachievable, 14, 16, 22, 23, 24, } 26 \\
\text { - treatment no longer achieves benefits for the patient, 15, 17, 22, 26 } \\
\text { - risk of suffering is greater than benefits, } 15,26 \\
\text { - treatment is in conflict with advance directives, } 26\end{array}$ & $\begin{array}{l}\text {-professional duty, } 13 \\
\text { - beneficence, } 15,17, \\
22,26 \\
\text { - nonmaleficence, } 15 \\
26 \\
\text { - autonomy, } 17,22 \\
23,26\end{array}$ \\
\hline & $\begin{array}{l}\text { There are no intrinsic moral } \\
\text { differences between } \\
\text { categories of treatment in a } \\
\text { decision to WH/WD } \\
\text { treatment }\end{array}$ & $\begin{array}{l}\text { - no intrinsic moral } \\
\text { difference exists between } \\
\text { categories of treatment } \\
\text { (cardiopulmonary } \\
\text { resuscitation, } \\
\text { ventilation...) in deciding } \\
\text { to WH/WD treatments, } \\
22\end{array}$ & & \\
\hline
\end{tabular}




\begin{tabular}{|c|c|c|c|}
\hline $\begin{array}{r}\text { Continuous deep } \\
\text { sedation }\end{array}$ & $\begin{array}{l}\text { Forgoing life-sustaining } \\
\text { treatments, palliative care } \\
\text { and terminal sedation are } \\
\text { not the same as euthanasia }\end{array}$ & $\begin{array}{l}\text { - doctrine of double effect defines the line between euthanasia and acceptable palliative care, } 17 \\
\text { - TS is justified under the rule of double effect when all other methods of controlling patient's } \\
\text { suffering have failed, } 14 \\
\text { - TS is palliative care, not euthanasia, it may arguably make the detection of euthanasia more } \\
\text { difficult, the intent of the physician is crucial, } 12 \\
\text { - there is an important distinction between killing and allowing to die- the withdrawal of life- } \\
\text { sustaining treatments is not legally considered a killing, } 15,17 \\
\text { - Active shortening of the dying process does not include withdrawing or withholding life- } \\
\text { sustaining treatment, } 23 \\
\text { - TS/PS is strictly differentiated from euthanasia in purpose and procedure (drugs and doses), as } \\
\text { well as in outcome, } 16 \\
\text { - WH/WD LST is not equivalent to medically assisted death or euthanasia, } 25\end{array}$ & - double effect, 14,17 \\
\hline
\end{tabular}

$T S$ terminal sedation, $T S / P C$ terminal sedation / palliative care, WH/WD LST withholding / withdrawing life-sustaining treatment, WH/WD withholding / withdrawing

${ }^{a}$ Not clear if the paper pertains to incapacitated patients 
Table 3. List of procedural positions with related supporting statements / additional information, ethical arguments and principles

\begin{tabular}{|c|c|c|c|c|}
\hline $\begin{array}{c}\text { THEMES } \\
\text { ACCORDING } \\
\text { TO CONTENT }\end{array}$ & PROCEDURAL POSITIONS & $\begin{array}{l}\text { SUPPORTING STATEMENT / } \\
\text { ADDITIONAL INFORMATION } \\
\text { (with references) }\end{array}$ & ETHICAL ARGUMENT (with references) & $\begin{array}{l}\text { ETHICAL PRINCIPLE } \\
\text { (with references) }\end{array}$ \\
\hline \multirow[t]{4}{*}{ Patient related } & $\begin{array}{l}\text { Patients' rights, wishes and } \\
\text { values should be respected }\end{array}$ & $\begin{array}{l}\text { - patient should know his beliefs and cultural } \\
\text { expectations will be met, } 14 \\
\text { - patient's wishes should be ascertained from } \\
\text { capable patient or surrogates when the patient is } \\
\text { not capable of making decisions, } 23 \\
\text { - patient's will can be expressed directly or } \\
\text { indirectly, } 12,15,18,19,24 \\
\text { - patient's desire, expressed in writing or } \\
\text { verbally, must be held in highest consideration, } \\
16\end{array}$ & $\begin{array}{l}\text { - principle of autonomy grants patients with decision-making } \\
\text { capacity the right to refuse any and all therapies, } 17,19,20,24,25 \\
\text { - based upon principles of autonomy, self-determination and privacy } \\
\text { particular decision made by patient may not be the right medical } \\
\text { decision, but it may be the most appropriate decision for that patient, } \\
13 \\
\text { - respecting patient's values has an important role in alleviating pain } \\
\text { and suffering, } 12 \\
\text { - patient's right to self-determination - refusal of treatment should be } \\
\text { respected, } 15 \\
\text { - Nonmaleficence requires the physician not to act contrary to the } \\
\text { patient's values and perspectives, } 19 \\
\text { - informed patient's decisions are primary and most weighty } \\
\text { considerations in almost all decisions regarding treatment, } 22 \\
\text { - respect for autonomy comprises respect for patient's decision not to } \\
\text { be involved in treatment decisions, } 25\end{array}$ & $\begin{array}{l}\text { - autonomy, } 13,15,17, \\
19,20,24,25 \\
\text { - privacy, } 13 \\
\text { - nonmaleficence, } 19\end{array}$ \\
\hline & $\begin{array}{l}\text { Patients' capacity should be } \\
\text { assessed }\end{array}$ & $\begin{array}{l}\text { - to have decision making capacity a list of } \\
\text { requirements must be satisfied, } 13,22,23 \\
\text { - physician is responsible for obtaining } \\
\text { assessment of capacity, } 22,23 \\
\text { - capacity should be evaluated on ongoing basis, } \\
\text { patient to resume authority when capacity is } \\
\text { regained if temporarily lost, } 22\end{array}$ & $\begin{array}{l}\text { - to be able to exercise his autonomy directly the patient should be } \\
\text { competent to make decisions and choices, } 19\end{array}$ & - autonomy, 19 \\
\hline & $\begin{array}{l}\text { Patients should be encouraged } \\
\text { to make advance care plans, } \\
\text { which should be respected }\end{array}$ & $\begin{array}{l}\text { - physicians should encourage patients to make } \\
\text { treatment plans in advance, } 13,22 \\
\text { - health care professionals should determine if } \\
\text { patient has advance directive, } 23 \\
\text { - incompetent patient's wishes should be } \\
\text { respected if expressed by advance directives, } 12 \text {, } \\
15,23 \\
\text { - public awareness about advance directives } \\
\text { should be encouraged, } 19 \\
\text { - verbally communicated wishes and preferences } \\
\text { made by informed and competent patient should } \\
\text { guide care in the same way as written } \\
\text { instructions, } 25\end{array}$ & $\begin{array}{l}\text { - advance care plans preserve autonomy in incapacitated patients, } 16 \text {, } \\
23,24,25 \\
\text { - to be binding, patient directive must be made after comprehensive } \\
\text { explanation of each medical intervention, } 18 \\
\text { - medical staff can ascertain real and conscious will of the patient if } \\
\text { his will is expressed within a program of medical advance planning, } \\
\text { thus it is ethically correct to respect the will of the patient, } 16\end{array}$ & - autonomy, 16, 23, 24, 25 \\
\hline & $\begin{array}{l}\text { Substitute judgement or } \\
\text { patient's best interest model } \\
\text { should be used when making a }\end{array}$ & $\begin{array}{l}\text {-substituted judgement model: surrogate makes } \\
\text { the decision the patient would likely make for } \\
\text { himself, } 13,15,17,23,24,25\end{array}$ & $\begin{array}{l}\text { - if patient has lost capacity, the right of autonomy is maintained } \\
\text { through other means: elicited form the next of kin or appointed liege } \\
\text { representative (substituted judgment), } 19\end{array}$ & - autonomy, 19 \\
\hline
\end{tabular}




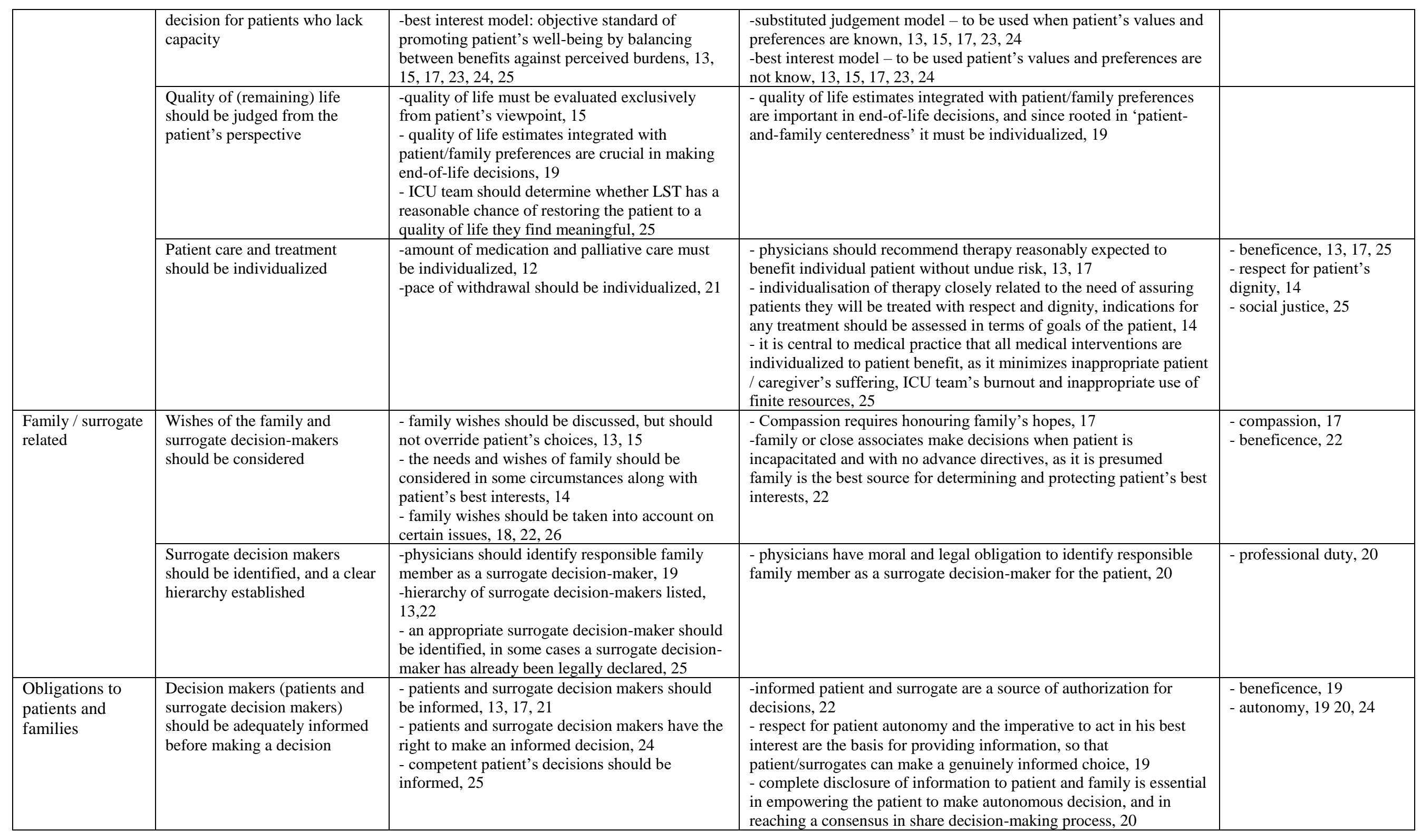




\begin{tabular}{|c|c|c|c|c|}
\hline & & & $\begin{array}{l}\text { - principle of respect for autonomy grants patients and surrogates the } \\
\text { right to be informed, } 24\end{array}$ & \\
\hline & $\begin{array}{l}\text { An informed consent should be } \\
\text { obtained from the patient or } \\
\text { surrogate }\end{array}$ & $\begin{array}{l}\text { - informed consent should be obtained, } 1619,23 \\
\text { - emergency exception to informed consent is } \\
\text { present - life saving treatments to be provided } \\
\text { without informed consent, } 23\end{array}$ & $\begin{array}{l}\text { - patient's right to self-determination must be respected, therefore } \\
\text { informed consent should be sought and obtained for any elective } \\
\text { invasive treatment, } 15 \\
\text { - informed patient's decisions are primary and most weighty } \\
\text { considerations in almost all decisions regarding treatment, } 22 \\
\text { - physicians required by law to respect informed patient's decision, } \\
20 \\
\text { - in order to respect patient's autonomy and serve the best interests of } \\
\text { the patient and family, they should be involved in an informed } \\
\text { decision-making process, } 19 \\
\text { - a competent patient or their substitute decision maker can provide } \\
\text { or refuse informed consent for a treatment plan when they reasonably } \\
\text { understand the diagnosis, risks, benefits and alternatives, } 25\end{array}$ & $\begin{array}{l}\text { - beneficence, } 19 \\
\text { - autonomy, } 15,19\end{array}$ \\
\hline & $\begin{array}{l}\text { Shared decision-making model } \\
\text { is the preferred way of making } \\
\text { end-of-life decisions }\end{array}$ & $\begin{array}{l}\text { - patients, surrogates and family should all be } \\
\text { participants in decision-making, } 15,16,22,24 \\
\text {-shared decision-making is a part of management } \\
\text { of end-of-life patients, } 14\end{array}$ & $\begin{array}{l}\text { - ethically sound medical decisions require patients and physicians } \\
\text { participating in mutual discussions resulting in jointly acceptable } \\
\text { decisions, it fosters a relationship between patients and professionals } \\
\text { characterized by mutual participation and respect, } 13 \\
\text { - physicians should make recommendations and guide families in } \\
\text { ways that accord with their decision-making preferences, } 17 \\
\text { - health care professionals should attempt to use shared decision } \\
\text { making to reach consensus that is in accordance with patient's values } \\
\text { and provides comfort to family and surrogates, } 23 \\
\text { - shared decision-making model respects dying patient's dignity and } \\
\text { needs of the family, } 16 \\
\text { - physician must work towards shared decision-making as it ensures } \\
\text { respect for patient's autonomy and fulfils his obligation of providing } \\
\text { beneficent care, } 19,20\end{array}$ & $\begin{array}{l}\text { - respect for patient's } \\
\text { dignity, } 16 \\
\text { - autonomy, } 20 \\
\text { - beneficence, } 20\end{array}$ \\
\hline & $\begin{array}{l}\text { Psychosocial needs of the } \\
\text { patients and family should be } \\
\text { met }\end{array}$ & $\begin{array}{l}\text { - support to patients and families should be } \\
\text { provided, } 13,14,18,20,21,22,23\end{array}$ & $\begin{array}{l}\text {-support of patient and family is a part of good palliative care, } 12,17 \\
\text { - physician should act in the best interests of patient and his family - } \\
\text { this responsibility extends beyond medical treatment by providing } \\
\text { compassionate care to the patient and attending to the emotional } \\
\text { needs of the family, } 19 \\
\text { - family must be protected from harm and posttraumatic stress } \\
\text { disorder, } 20\end{array}$ & $\begin{array}{l}\text { - beneficence, } 19 \\
\text { - nonmaleficence, } 20\end{array}$ \\
\hline $\begin{array}{l}\text { Medical team } \\
\text { related }\end{array}$ & $\begin{array}{l}\text { Values of ICU team must not } \\
\text { interfere with the provision of } \\
\text { unbiased and non-judgmental } \\
\text { care }\end{array}$ & $\begin{array}{l}\text {-physicians should guard against imposing their } \\
\text { own values on end-of-life decisions or be in any } \\
\text { way manipulative or coercive, } 19 \\
\text { - individual views of the ICU team members must } \\
\text { not interfere with the provision of unbiased and } \\
\text { non-judgmental care, } 25\end{array}$ & $\begin{array}{l}\text { - ICU team must recognize their values and perception to assure } \\
\text { optimal delivery of care in non-judgmental fashion, } 13,24\end{array}$ & \\
\hline
\end{tabular}




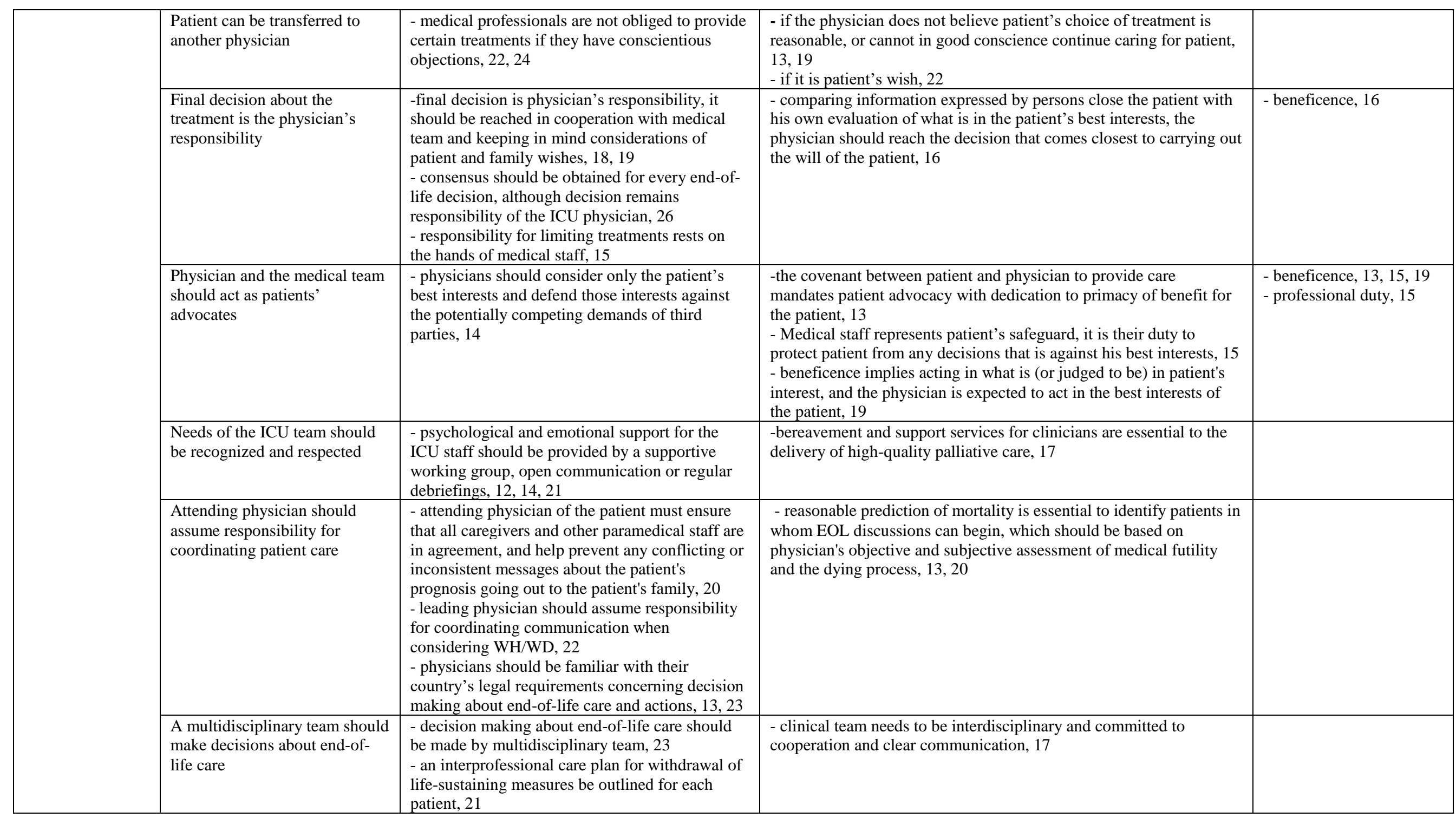




\begin{tabular}{|c|c|c|c|c|}
\hline & & $\begin{array}{l}\text { - ICU team may seek additional consultation of } \\
\text { other relevant clinicians or ethicists to determine } \\
\text { if LST should be WH/WD, } 25\end{array}$ & & \\
\hline & $\begin{array}{l}\text { Education of staff should be } \\
\text { encouraged }\end{array}$ & $\begin{array}{l}\text { - further education of ICU team is needed, } 12,14 \text {, } \\
17\end{array}$ & $\begin{array}{l}\text { - health care professionals should be educated in the core end-of-life } \\
\text { skills, so they become expert in decision making at the end of life and } \\
\text { the practical aspects of end-of-life care in accord with the cultural, } \\
\text { legal, and religious norms of their practice environment, } 23\end{array}$ & \\
\hline \multirow[t]{4}{*}{$\begin{array}{l}\text { Treatment } \\
\text { justification }\end{array}$} & $\begin{array}{l}\text { Patient's wishes may be } \\
\text { overridden in certain situations }\end{array}$ & $\begin{array}{l}\text {-advance directives should not be followed when } \\
\text { proposed action is prohibited by the country's } \\
\text { laws, where there is compelling evidence that the } \\
\text { patient may have changed his mind since } \\
\text { completing the advance directive, when there is } \\
\text { compelling evidence suggesting that the patient } \\
\text { did not understand the nature of the advance } \\
\text { directive he completed, } 23\end{array}$ & $\begin{array}{l}\text {-it is ethical to decline to provide treatment which is judged not to be } \\
\text { in the interests of the patient, or where there are insufficient resources } \\
\text { to provide treatment of this level of benefit, } 20 \\
\text { - decision inconsistent with values or violating patient's best } \\
\text { interests, made while patient's capacity is uncertain, } 22 \\
\text { - when treatment provides no medical benefit, } 24,25 \\
\text { - when treatment falls outside of accepted medical practice, } 17,24 \text {, } \\
25 \\
\text { - when it is not possible to decide if the will expressed corresponds to } \\
\text { patient's presumed long-term will, } 15 \\
\text { - when treatments are harmful to patients, } 23\end{array}$ & $\begin{array}{l}\text { - beneficence, } 20,22 \\
\text { - social justice, } 20 \\
\text { - nonmaleficence, } 23\end{array}$ \\
\hline & $\begin{array}{l}\text { Certain medical therapies or } \\
\text { procedures with no reasonable } \\
\text { medical benefit can be provided } \\
\text { to the patient }\end{array}$ & & $\begin{array}{l}\text { - if meaningful to the patient and it establishes a mutually satisfactory } \\
\text { course of treatment, } 22 \\
\text { - until completion of all reasonable social and spiritual obligations, as } \\
\text { beneficence and compassion require to support patient and relatives } \\
\text { during the dying process, } 24,25 \\
\text { - because of the psychological benefits, } 14 \\
\text { - in order to give relatives time to reach the hospital, } 18 \\
\text { - to reduce psycho-physical suffering of individual patient, } 15\end{array}$ & $\begin{array}{l}\text { - beneficence, } 24,25 \\
\text { - compassion, } 24,25\end{array}$ \\
\hline & $\begin{array}{l}\text { Treatment goals should be } \\
\text { regularly evaluated }\end{array}$ & $\begin{array}{l}\text { - once the transition from cure to comfort has } \\
\text { been negotiated therapies should be critically } \\
\text { evaluated in terms of whether they make a net } \\
\text { positive contribution to the comfort of the patient, } \\
17\end{array}$ & $\begin{array}{l}\text { - evaluation at appropriate intervals to determine if it is achieving } \\
\text { goals and benefits that justified its initial use, } 13,18,22,24 \\
\text { - central to medical practice that all medical interventions are } \\
\text { routinely reassessed as it minimizes inappropriate patient / } \\
\text { caregiver's suffering, ICU team's burnout and inappropriate use of } \\
\text { finite resources, } 25\end{array}$ & -social justice, 25 \\
\hline & $\begin{array}{l}\text { Limited resources should be } \\
\text { fairly allocated }\end{array}$ & $\begin{array}{l}\text { - due to expensiveness of ICU care economic } \\
\text { concerns are legitimate part of considerations in } \\
\text { ethical discussions, } 13 \\
\text { - medical staff who take decisions on admission } \\
\text { are morally responsible for fair allocation of } \\
\text { resources assigned to them, } 15\end{array}$ & $\begin{array}{l}\text { - all patients should have equitable access to life-supportive care, } \\
\text { allocation of resources should be unbiased in a way which maximizes } \\
\text { chances of successful intensive care treatment, } 24 \\
\text { - the principle of proportionality of care states that therapies should } \\
\text { only be administered in proportion to expected benefits, } 26 \\
\text { - decisions regarding intensive medical care should be based on the } \\
\text { fundamental ethical principles of fair use of available means, } 18 \\
\text { - physicians need to have a socially responsible behaviour, which } \\
\text { makes it their duty to make optimal use of the material, financial and } \\
\text { human resources under their control, } 19\end{array}$ & $\begin{array}{l}\text { - social justice, } 24,25 \\
\text { - proportionality of care, } \\
26 \\
\text { - beneficence, } 20,26 \\
\text { - fairness, } 18 \\
\text { - professional duty, } 19\end{array}$ \\
\hline
\end{tabular}




\begin{tabular}{|c|c|c|c|c|}
\hline & & & $\begin{array}{l}\text {-social justice means allocating resources appropriate to the medical } \\
\text { condition of the patient in order to maximize their benefits and } \\
\text { minimize wastage, } 20 \\
\text { - justice is a principle by which all patients should have equitable } \\
\text { access to healthcare, } 25\end{array}$ & \\
\hline & $\begin{array}{l}\text { ICU care should be initiated or } \\
\text { continued in cases of } \\
\text { disagreement, reasonable doubt } \\
\text { or uncertainty about patient's } \\
\text { condition or wishes }\end{array}$ & $\begin{array}{l}\text {-treatment should be initiated when in doubt } \\
\text { about patient's condition or wishes, } 13,15,16 \text {, } \\
24,25 \\
\text { - treatment should be continued in case of } \\
\text { disagreement or pending consensus on limitation } \\
\text { of treatment, } 19,20,24\end{array}$ & $\begin{array}{l}\text { - in case of conflict with relatives, therapy should be continued in } \\
\text { order to provide them with time to gain a better understanding of the } \\
\text { situation and accept it, } 18\end{array}$ & \\
\hline \multirow[t]{3}{*}{ Transparency } & $\begin{array}{l}\text { Consensus between the } \\
\text { members of the medical team } \\
\text { regarding goals and strategies } \\
\text { of treatment should be } \\
\text { established }\end{array}$ & $\begin{array}{l}\text {-consensus between the members of medical team } \\
\text { should be established when making a WH/WD } \\
\text { decision, } 15,18,19,20,23,24,26,25\end{array}$ & $\begin{array}{l}\text { - consensus between clinicians should be established in order to } \\
\text { deliver a consistent message, } 14 \\
\text { - it is essential to agree upon the best care for the patient to overcome } \\
\text { eventual conflicts among physicians, } 16\end{array}$ & \\
\hline & $\begin{array}{l}\text { Good medical records should be } \\
\text { kept }\end{array}$ & $\begin{array}{l}\text { - all decisions regarding decision-making process } \\
\text { in patients without capacity should be noted, } 13 \text {, } \\
15 \\
\text { - decision and rationale for WH/WD should be } \\
\text { recorded, } 22,23,16 \\
\text { - disagreement between family and competent } \\
\text { patient should be recorded, } 24,25 \\
\text { - all end-of-life care planning should be clearly } \\
\text { documented, } 26,25 \\
\text { - documenting the rationale for giving any dose } \\
\text { of comfort medication during withdrawal is } \\
\text { recommended, } 21 \\
\text { - verbally communicated wishes and preferences } \\
\text { made by informed and competent patient should } \\
\text { be documented, } 25\end{array}$ & $\begin{array}{l}\text { - provides a means of assessing physician's intention when } \\
\text { administering narcotics/sedatives to palliate dying patients, } 12,14,17 \\
\text { - helps all team members understand reasons for the decision, ensures } \\
\text { unambiguous way of proceeding after a shift change, } 18 \\
\text { - ensures transparency and accuracy, provides evidence of an } \\
\text { evolving decision-making process that indicates appropriate care on } \\
\text { the part of the physician, } 19,20\end{array}$ & - transparency, 19 \\
\hline & $\begin{array}{l}\text { Effective communication with } \\
\text { the patient, family, surrogates } \\
\text { and between ICU team is of } \\
\text { paramount importance }\end{array}$ & $\begin{array}{l}\text { - communication between patients, family and } \\
\text { ICU team is of paramount importance, all } \\
\text { members of ICU team should be aware of } \\
\text { decision to WH/WD treatment, } 22 \\
\text { - health care professionals should communicate } \\
\text { important medical information to patients and } \\
\text { families, } 23,25 \\
\text { - plans for end-of-life care in each individual } \\
\text { patient should be discussed with and understood } \\
\text { by the relatives, } 26\end{array}$ & $\begin{array}{l}\text { - communication skills are an important component of high-quality } \\
\text { critical care, } 17 \\
\text { Communication within ICU team: } \\
\text { - provides support to patients and family, } 13,25 \\
\text { - achieves consistency in communication towards patient/family and } \\
\text { with involved consulting services, } 24 \\
\text { Communication with patients and surrogates: } \\
\text { - enhances mutual trust, } 24,25 \\
\text { - diminishes conflict, } 15,16,17,19,24,25\end{array}$ & - beneficence, 15,16 \\
\hline
\end{tabular}




\begin{tabular}{|c|c|c|c|c|}
\hline & & $\begin{array}{l}\text { - physicians and nurses should communicate } \\
\text { clearly about the patient's comfort level, } 18,21\end{array}$ & $\begin{array}{l}\text { - alleviates anxiety, } 14,16,17 \\
\text { - improves abilities of physicians and nurses to determine patient } \\
\text { suffering, } 12 \\
\text { - helps in making appropriate decisions in patient's best interest, } 15 \text {, } \\
16 \\
\text { - facilitates achieving consensus, } 15,20 \\
\text { - facilitates transition from curative to palliative care, } 19,20 \\
\text { - provides accurate and appropriate information about the disease } \\
\text { process, } 20\end{array}$ & \\
\hline & $\begin{array}{l}\text { Disagreements between parties } \\
\text { on any level should be resolved }\end{array}$ & $\begin{array}{l}\text { - disagreements should be resolved by; } \\
\text { - further communication, } 13,15,16,17,19,20 \text {, } \\
24,25 \\
\text { - institutional dispute resolution mechanism (i.e. } \\
\text { ethics committee), } 13,15,16,17,19,20,22,23, \\
24,25 \\
\text { - transfer of care to another physician, 13, 19, 22, } \\
24,25 \\
\text { - courts, } 13,20,22,24, \\
\text { - independent opinions from third parties, } 24,18 \text {, } \\
\text { 19, } 20,25 \\
\text { - external advisory body with appropriate } \\
\text { qualifications, } 18\end{array}$ & $\begin{array}{l}\text { - ethics committees should not make E-o-L decisions - individuals } \\
\text { who are not in immediate contact with the affected patients and with } \\
\text { those concerned with critical care medicine seldom have the requisite } \\
\text { insight and experience to make any substantial contribution to the } \\
\text { decision-making process, } 18\end{array}$ & \\
\hline \multirow[t]{2}{*}{$\begin{array}{l}\text { General } \\
\text { principles of ICU }\end{array}$} & $\begin{array}{l}\text { Admission to ICU can be } \\
\text { denied }\end{array}$ & $\begin{array}{l}\text {-patients, families, and health care providers } \\
\text { should be educated about appropriateness of ICU } \\
\text { admission, and detailed on alternatives to ICU } \\
\text { admission in order to prevent any malfeasance, } \\
20\end{array}$ & $\begin{array}{l}\text { - if deemed impossible to achieve treatment goals, } 15,16,18,24 \\
\text { - if treatment not in accord with standard medical practice, } 24 \\
\text { - if risks and suffering greater than benefits, } 15 \\
\text { - treatment failure after a trial period, } 16 \\
\text { - principle of fairness requires all patients be treated in the same way, } \\
\text { therefore it is ethically justifiable to restrict use of ICU care on the } \\
\text { basis of clinical appropriateness, } 15 \\
\text { - restricted access to ICU should not be considered as abandonment } \\
\text { of dying patients, but rather the appropriate consideration of patient's } \\
\text { needs, based on the bioethical principles of autonomy (conscious } \\
\text { patient's denial of treatment or living will), benevolence and the } \\
\text { absence of malice, } 16 \\
\text {-principle of social justice commits us that all patients should have } \\
\text { equitable access to life-supportive care, unless that care has no } \\
\text { rational expectation of an outcome acceptable to the patient, } 24 \\
\text { - admission to ICU should be based on the existence of a positive } \\
\text { prospect of patient survival, otherwise it violates the ethical principle } \\
\text { of fair and just distribution of resources, } 18\end{array}$ & $\begin{array}{l}\text { - social justice, } 18,24 \\
\text { - fairness, } 15 \\
\text { - autonomy, } 16 \\
\text { - beneficence, } 16 \\
\text { - nonmaleficence, } 16,20\end{array}$ \\
\hline & $\begin{array}{l}\text { Every ICU should establish } \\
\text { certain formal rules and } \\
\text { protocols }\end{array}$ & $\begin{array}{l}\text {-every ICU should establish formal rules in } \\
\text { accordance with which participants are included } \\
\text { and discussion procedures carried out, } 18\end{array}$ & & \\
\hline
\end{tabular}




\begin{tabular}{|l|l|l|l|}
\hline & & $\begin{array}{l}\text { - institutions / health regions should establish a } \\
\text { reporting process among the healthcare team that } \\
\text { regularly reviews issues of discussions about } \\
\text { WH/WD LST, 25 }\end{array}$ & \\
\hline Miscellaneous & $\begin{array}{l}\text { After death care should be } \\
\text { provided to all dying patients }\end{array}$ & $\begin{array}{l}\text {-culturally appropriate and sensitive after death } \\
\text { care should be provided to all the dying patients } \\
\text { irrespective of the situation or the setting, 20 }\end{array}$ & \\
\cline { 2 - 5 } & $\begin{array}{l}\text { Organ donation is an integral } \\
\text { part of end-of-life decisions }\end{array}$ & $\begin{array}{l}\text {-discussions about organ donation should be led } \\
\text { by a specially trained person, 14 } \\
\text {-requests on organ donation should allow families } \\
\text { opportunity to determine if it is consistent with } \\
\text { patient's wishes, 17 }\end{array}$ & \\
\hline
\end{tabular}




\section{$\underline{3.4 \text { Ethical principles }}$}

Twelve different ethical principles emerged from the ethical arguments for a total of 26 substantive and procedural positions (see table 4). Some positions are based on only one principle, while others on as much as 5 . Overall, the most frequently used principles are the principles of beneficence, autonomy and nonmaleficence.

In the substantive positions 8 principles arise. The principle of nonmaleficence and beneficence are most frequent, followed by the principles of professional duty. The doctrine of double effect is mentioned only in the substantive group. In the procedural positions 11 principles emerge. The principles of beneficence, nonmaleficence and autonomy are most frequently used. Principles of privacy, compassion, fairness and transparency are mentioned only in the procedural group.

The principle of self-determination was mentioned in two papers separately from the principle of autonomy. However, both principles are supported by same ethical arguments and, as they encompass same ideas, the principle of self-determination was here grouped under the principle of autonomy.

The principle of fairness which usually conveys the same meaning as the principle of social justice was mentioned in two papers and is mentioned here as a separate principle as it pertains to slightly different ethical arguments than the principle of social justice regarding the same categories of positions.

Table 4. List of ethical principles and related categories of positions

\begin{tabular}{|c|l|}
\hline PRINCIPLE & \multicolumn{1}{|c|}{ RELATED CATEGORIES OF POSITIONS (with references) } \\
\hline \multirow{5}{*}{ Autonomy } & $\begin{array}{l}\text {-Patients' rights, wishes and values should be respected, 13, 17, 19, 20, 24, 25 } \\
\text { - Patients' capacity should be assessed, 19 } \\
\text { - Patients should be encouraged to make advance care plans, which should be respected, 16, 23, 24, 25 } \\
\text { - Substitute judgement or patient's best interest model should be used when making a decision for patients } \\
\text { who lack capacity, 19 }\end{array}$ \\
- Decision makers (patients and surrogate decision makers) should be adequately informed before making a \\
decision, 19, 20, 24 \\
- An informed consent should be obtained from the patient or surrogate, 19 \\
- Shared decision-making model is the preferred way of making end-of-life decisions, 20 \\
- Palliative care should be provided to all ICU patients, until the end of their lives, 23 \\
- Withholding and withdrawing of treatment are morally equal, and permissible, 17, 22, 23, 26
\end{tabular}




\begin{tabular}{|c|c|}
\hline $\begin{array}{c}\text { Respect for } \\
\text { patient's dignity }\end{array}$ & $\begin{array}{l}\text { - Patient care and treatment should be individualized, } 14 \\
\text { - Shared decision-making model is the preferred way of making end-of-life decisions, } 16 \\
\text { - Patients' pain and suffering should be alleviated, even if it may hasten death, } 22,25 \\
\text { - Palliative care should be provided to all ICU patients, until the end of their lives, } 23 \\
\text { - Medically futile treatments - that offer no benefit to the patient - should not be offered, started or maintained, } \\
15\end{array}$ \\
\hline Compassion & $\begin{array}{l}\text { - Wishes of the family and surrogate decision-makers should be considered, } 17 \\
\text { - Certain medical therapies or procedures with no reasonable medical benefit can be provided to the patient, } \\
24,25\end{array}$ \\
\hline Beneficence & $\begin{array}{l}\text { - Patient care and treatment should be individualized, } 13,17,25 \\
\text { - Wishes of the family and surrogate decision-makers should be considered, } 22 \\
\text { - Decision makers (patients and surrogate decision makers) should be adequately informed before making a } \\
\text { decision, } 19 \\
\text { - An informed consent should be obtained from the patient or surrogate, } 19 \\
\text { - Shared decision-making model is the preferred way of making end-of-life decisions, } 20 \\
\text { - Psychosocial needs of the patients and family should be met, } 19 \\
\text { - Final decision about the treatment is the physician's responsibility, } 16 \\
\text { - Physician and the medical team should act as patients' advocates, } 13,15,19 \\
\text { - Patient's wishes may be overridden in certain situations, } 20,22 \\
\text { - Certain medical therapies or procedures with no reasonable medical benefit can be provided to the patient, } \\
24,25 \\
\text { - Limited resources should be fairly allocated, } 20,26 \\
\text { - Effective communication with the patient, family, surrogates and between ICU team is of paramount } \\
\text { importance, } 15,16 \\
\text { - Admission to ICU can be denied, } 16 \\
\text { - Patients' pain and suffering should be alleviated, even if it may hasten death, } 25 \\
\text { - Palliative care should be provided to all ICU patients, until the end of their lives, } 19 \\
\text { - Medically futile treatments - that offer no benefit to the patient - should not be offered, started or maintained, } \\
20 \\
\text { - The dying process should not be prolonged, } 18,19,23 \\
\text { - Withholding and withdrawing of treatment are morally equal, and permissible, } 15,17,22,26\end{array}$ \\
\hline $\begin{array}{l}\text { Professional } \\
\text { duty }\end{array}$ & $\begin{array}{l}\text { - Surrogate decision makers should be identified, and a clear hierarchy established, } 20 \\
\text { - Physician and the medical team should act as patients' advocates, } 15 \\
\text { - Limited resources should be fairly allocated, } 19 \\
\text { - Patients' pain and suffering should be alleviated, even if it may hasten death, 14, 15, 16, } 19 \\
\text { - Palliative care should be provided to all ICU patients, until the end of their lives, } 16 \\
\text { - The dying process should not be prolonged, 16, } 18 \\
\text { - Withholding and withdrawing of treatment are morally equal, and permissible, } 13\end{array}$ \\
\hline Social justice & $\begin{array}{l}\text { - Patient's wishes may be overridden in certain situations, } 20 \\
\text { - Patient care and treatment should be individualized, } 25 \\
\text { - Treatment goals should be regularly evaluated, } 25 \\
\text { - Limited resources should be fairly allocated, } 24,25 \\
\text { - Admission to ICU can be denied, } 18,24 \\
\text { - Medically futile treatments - that offer no benefit to the patient - should not be offered, started or maintained, } \\
15,20\end{array}$ \\
\hline $\begin{array}{l}\text { Proportionality } \\
\text { of care }\end{array}$ & $\begin{array}{l}\text { - Limited resources should be fairly allocated, } 26 \\
\text { - Medically futile treatments - that offer no benefit to the patient - should not be offered, started or maintained, } \\
26 \\
\text { - The dying process should not be prolonged, } 26\end{array}$ \\
\hline Transparency & - Good medical records should be kept, 19 \\
\hline Fairness & $\begin{array}{l}\text { - Limited resources should be fairly allocated, } 18 \\
\text { - Admission to ICU can be denied, } 15\end{array}$ \\
\hline
\end{tabular}




\section{Discussion}

The overall aim of this review was to analyse papers tackling ethical issues in relation to end-of-life decision-making in ICUs, by exploring the ethical positions, arguments and principles. Our analysis shows there are several ethical positions which are mentioned in a large percentage of the included papers, meaning that a certain level of agreement, at least in the theoretical scope, exists. This discussion is focused on the most frequently identified ethical positions in our review.

Communication between all involved parties and on all levels is mentioned in all included papers. It is of paramount importance and has direct influence on all aspects of care as it enhances trust, provides support to patients and families, decreases conflict and aids in making timely and appropriate decisions [24, 25].

However, insufficient and inadequate communication between the medical team and the family is common and can have serious consequences [28]. Hinkle et al. explored factors associated with family satisfaction with end-of-life care in critically ill adult population and found that higher satisfaction is related to good communication [29]. A literature review conducted by Morgan concerning end-of-life care in adult critical care units in UK confirms that, as it was found that poor communication with families is the most commonly documented source of dissatisfaction, while skilful communication is considered as a means to resolve conflict [30].

Good communication is a vital component of quality critical care and key in upholding other recommendations, such as: respect for patient's wishes and values, informing the decision makers, obtaining informed consent, establishing consensus between members of the medical team, resolution of disagreements. In other words, good communication is a critical precondition underlying other recommendations and ethical principles, such as autonomy and nonmaleficence. Therefore, in everyday practice, it needs to be implemented to the fullest possible extent.

Our analysis yields only one ethical principle directly pertaining to communication - beneficence. It is mentioned in two included papers stating that it helps in making appropriate decisions in the patient's best interest, which is not surprising concerning all of the effects good communication has on end-of-life decision-making. 
Keeping good medical records is another ethical position mentioned in all included papers. It indicates appropriate care, provides a means of assessing physician's intentions, and helps all team members discern the reasons behind the decisions. Reasons for the decision to withhold or withdraw life-sustaining treatment should be entered in the patient's medical record [1].

A retrospective study conducted by Kirchhoff et al. concluded that comprehensive documentation of endof-life care in ICU is lacking [31]. Such findings are unfortunate, as careful documentation provides a way of ensuring transparency, which is the only ethical principle ascribed to this position and identified in our review. Even though our review did not identify ethical principles of professional duty and doctrine of double effect underpinning the position of good medical records, they are connected. Physicians' professional duties entail the provision of good standard of practice and care. By noting in the medical records each aspect of care provided, physicians confirm and leave physical trace of their conduct and fulfilment of obligations towards patients. Improperly kept medical records are not equivalent to inadequate standard of practice and care. However, in striving for betterment and provision of wholesome end-of-life care, good medical records should be kept, and both principles of professional duty and transparency upheld. The principle/doctrine of double effect allows for patient's suffering to be alleviated even if it may hasten death, under the justification that death was not intended, but merely a foreseeable side-effect. In end-of-life situations it is the intent that makes a difference whether a patient's death following an administration of sedatives and narcotics is an unethical, or even felonious act or not. Adequately kept medical records enable the assessment of physician's intentions, provide clear explanation and rationale for decisions made, and ensure physician's innocence if ever being scrutinised.

Our review found that alleviation of patient's pain and suffering, even if it may hasten death, is a widely accepted ethical position, also mentioned in all included papers. It is closely related to the position that palliative care should be provided to all ICU patients, until the end of their lives, though the two differ. Provision of palliative care encompasses relief of suffering, but also psychological and spiritual support of patient and their closest ones, and provision of comfort. Both positions are supported by ethical principles of respect for patient's dignity, professional duty and non-maleficence.

Lemiengre et al. found that the prevalence of ethics policies on pain and symptom control is low in written institutional policies on end-of-life decisions [32], while Mast et al. found a lack of palliative care content and pain management in the context of end-of-life care in nationally developed guidelines for chronic, non-curable, life- 
limiting diseases [33]. Our findings suggest that both positions are extensively recognized as being significant in end-of-life decision-making process, therefore they should be more often mentioned and thoroughly elaborated in other guidelines related to end-of-life issues. Perhaps the reason for the discrepancies lies in the fact that our research focused on units of intensive and critical care, where decisions must be made much more swiftly, and the medical team is possibly more experienced in administering opioid and sedative medication. Especially as it is accepted that palliative care must be instigated from the moment the patient enters the ICU [28].

The position that withholding and withdrawing of treatment are morally equivalent, and permissible was confirmed by all of the included papers in our review. It is supported by several ethical principles: professional duty, beneficence, non-maleficence and autonomy. However, there are some minority opinions and cultural differences which do not equate the two. [34, 35, 36].

Furthermore, studies researching practical aspects of end-of-life care in ICUs have showed that withholding treatment is more common than withdrawing $[37,38]$. This suggests that, even though there seem to be no apparent ethical dilemmas, there are other factors influencing the decision-making process. It is suggested that the reason for differences (be it international, or within the same country, even the same ICU) is rooted in socio-cultural diversity, legal context, patient characteristics, and physicians' beliefs, practices and prior experiences [39, 35]. The ETHICUS study has shown regional differences in Europe, and that religious affiliation affects physician's decisions on the matter [38]. Withholding of treatment is perceived as less difficult and more of a passive action, even though the end result is the same. A general increase in both withholding and withdrawing of life-sustaining treatments has been noted in European ICUs [39, 40]. Perhaps, with time there will be a decrease in difference in frequency of withholding in comparison to withdrawing life-sustaining treatments as both actions become more common, the respect for patient autonomy takes even more sway and more patients make advanced care plans.

The intentional shortening of the dying process is supported in only one of the included papers [26]. Nonetheless, studies confirm that it happens on rare occasions in several countries [38, 41]. Most countries do not allow the shortening of the dying process under current law regulations, meaning potentially illegal actions are taking place. Furthermore, the question of informing the patient and family members arises. Most shortening of the dying process therapies are preceded by withholding or withdrawing of treatment [38]. As those actions are 
common and legal in most countries, one assumes that the patient and family members were included in the discussion and informed about the decision. On the other hand, it can be presumed that in some cases of shortening of the dying process, due to the delicacy, sensitivity, and legal relativity of the situation, patients and family members have not been informed. This indicates another gap between theory and practice, and an important one.

When it comes to disagreements on any level about treatment of patients, most of the included papers recommend several ways of resolution, starting from communication and its improvement, and leading up to judiciary institutions. Ten of the papers propose that disputes be resolved by an institutional mechanism - the ethics committee. However, the recommendations of Austrian associations of intensive care medicine do not support such a view [18]. When describing the process of decision-making and the relevant parties, (and) not the process of disagreement resolution per se, they express the opinion that decisions on therapy limitation and discontinuation should be reached on the basis of medical facts, and that the individuals who are not in direct contact with the patient, or are not concerned with critical care medicine, do not possess the requisite insight and experience to make substantial contribution in the decision-making process.

A study conducted by Schneiderman et al. has shown that ethics consultations in ICU lead to significant reduction in nonbeneficial treatments, and it was agreed by both medical professionals, patients and surrogate decision makers that ethics consultations are helpful in addressing treatment conflicts [42]. It has been shown that both ethics and palliative care consultations lead to a reduced length of stay in the ICU, and even a reduced number of ICU admissions for patients at high risk of death if the palliative care consultations occurred upon hospitalization $[43,44]$. (Ethies consultations can be provided by an individual, a team, or a committee.) Palliative care experts try to improve the quality of dying and death (including ethical and legal aspects of decision making, the goal-setting with families experiencing high levels of distress or conflicts among members), all the while reducing the burden for caregivers, and possessing the required experience, knowledge and understanding [45]. In the cases where critical care societies or institutions do not recommend consultations by ethics committees or persons who are usually not involved with the patients or are not involved in critical care, a potential solution could be reached by providing palliative care consultation services.

The first step towards a better implementation of mentioned recommendations, which would lead towards a better end-of-life care in general, is education. Four of the included papers mention the significance of further education of ICU team members, as it would enable them to become expert in decision making and the practical aspects of end-of-life care which are in accord with the cultural, legal, and religious norms of practice environment. 
Enhanced professional education and training are the way for the necessary changes to ensure that all critically ill patients and their families obtain an excellent level of palliative care able to successfully meet their needs [45].

This systematic review has several limitations. Only papers in English were included, which may have led to the omission of other pertinent papers. The papers predominantly originate from western European and North American countries which share similar socio-economic conditions, leading to potentially distorted results of similarity in promoted ethical positions.

\section{Conclusion}

We have demonstrated that recommendations and guidelines designed specifically by intensive or critical care experts for ICUs end-of-life care promote similar ethical positions, with minimal dissenting positions. However, some of the included papers do not provide ethical arguments nor principles for proposed positions, which could be considered as essential in order to be able to comprehensively judge their content and ensure ethical coherence/traceability. This is of critical importance due to the high variability of decision-making process and its final outcomes, and inadequate implementation of these seemingly widely shared propositions, as shown in previously mentioned studies [28, 31, 33, 38].

(This is of critical importance as other studies show(s) inadequate implementation of these seemingly widely shared propositions, and due to the high variability of decision-making process and its final outcomes.)

Further research is warranted in order to detect differences, if there are any, between ethical content of end-of-life decision-making in ICUs and on other medical wards and in other institutions.

\section{Acknowledgements: Not applicable}

Funding: This article is a part of 'Values and decisions at the end of life' (VAL-DE-END) project funded by Croatian Science Foundation (grant number: IP-2016-06-2721). (The sponsor had no role in study design; in the collection, analysis and interpretation of data; in the writing; and in the decision to submit the article for publication)

\section{Declarations of interests: None}




\section{References}

[1] Curtis JR, Vincent JL. Ethics and end-of-life care for adults in the intensive care unit. Lancet 2010;376:1347-

53. https://doi.org/10.1016/S0140-6736(10)60143-2

[2] Cook D, Rocker G. Dying with dignity in the intensive care unit. N Engl J Med 2014;370:2506-14. http://doi.org/10.1056/NEJMra1208795

[3] Joynt GM, Lipman J, Hartog C, Guidet B, Paruk F, Feldman C, et al. The Durban World Congress Ethics

Round Table IV: Health care professional end-of-life decision making. J Crit Care 2015;30:224-30.

https://doi.org/10.1016/j.jcrc.2014.10.011

[4] Mark NM, Rayner SG, Lee, JR, Curtis JR. Global variability in the withdrawal of life-sustaining treatment in the intensive care unit: a systematic review. Intensive Care Med 2015;41:1572-85.

http://doi.org/10.1007/s00134-015-3810-5

[5] Myburgh J, Abillama F, Chiumello D, Dobb G, Jacobe S, Kleinpell R, et al. End-of-life care in the intensive care unit: Report from the Task Force of World Federation of Societies of Intensive and Critical Care Medicine.

J Crit Care 2016;34:125-30.

[6] WHO Expert Committee on Cancer Pain Relief and Active Supportive Care. Cancer pain relief and palliative care: report of a WHO expert committee https://apps.who.int/iris/handle/10665/39524; 1990 [accessed 10 January 2020].

[7] Moher D, Liberati A, Tetzlaff J, Altman DG. Preferred reporting items for systematic reviews and metaanalyses: the PRISMA statement. Ann Intern Med 2009;151:264-9. http://doi.org/10.7326/0003-4819-151-4200908180-00135

[8] Lefebvre C, Manheimer E, Glanville J. Searching for studies. In: Higgins JPT, Green S, editors. Cochrane Handbook for Systematic Reviews of Interventions Version 5.1.0 [updated March 2011]. The Cochrane Collaboration, 2011. Available from www.handbook.cochrane.org.

[9] Dye JF, Schatz IM, Rosenberg BA, Coleman ST. Constant Comparison Method: A Kaleidoscope of Data. Qual Rep 2000;4:1-10.

[10] Boeije HR. A Purposeful Approach to the Constant Comparative Method in the Analysis of Qualitative Interviews. Qual Quant 2002;36:391-409. https://doi.org/10.1023/A:1020909529486

[11] Mezinska S, Kakuk P, Mijaljica G, Waligóra M, O'Mathúna DP. Research in disaster settings: a systematic qualitative review of ethical guidelines. BMC Med Ethics 2016;17:62. https://doi.org/10.1186/s12910-016-01487

[12] Hawryluck LA, Harvey WRC, Lemieux-Charles L, Singer PA. Consensus guidelines on analgesia and sedation in dying intensive care unit patients. BMC Med Ethics 2002;3:E3. https://doi.org/10.1186/1472-6939-33

[13] Bone RC, Rackow EC, Weg JG. Ethical and Moral Guidelines for the Initiation, Continuation, and Withdrawal of Intensive Care. Chest 1990;97(4):949-58.

[14] Truog RD, Cist AFM, Brackett SE, Burns JP, Curley MAQ, Danis M, et al. Recommendations for end-oflife care in the intensive care unit: The Ethics Committee of the Society of Critical Care Medicine. Crit Care Med 2001;29(12):2332-48. http://doi.org/10.1097/00003246-200112000-00017

[15] Gruppo di Studio ad Hoc della Commissione di Bioetica della SIAARTI. SIAARTI guidelines for admission to and discharge from Intensive Care Units and for the limitation of treatment in intensive care. Minerva Anestesiol 2003;69:101-18.

[16] SIAARTI - Italian Society of Anesthesia, Analgesia, Resuscitation and Intensive Care Bioethical Bord. End-of-life care and the intensivist: SIAARTI recommendations on the management of the dying patient.

Minerva Anestesiol 2006;72:927-63.

[17] Truog RD, Campbell ML, Curtis JR, Haas CE, Luce JM, Rubenfeld GD,et al. Recommendations for end-oflife care in the intensive care unit: A consensus statement by the American College of Critical Care Medicine. Crit Care Med 2008;36(3):953-63. http://doi.org/10.1097/CCM.0B013E3181659096

[18] Valentin A, Druml W, Steltzer H, Wiedermann CJ. Recommendations on therapy limitation and therapy discontinuation in intensive care units: Consensus Paper of the Austrian Associations of Intensive Care Medicine. Intensive Care Med 2008;34:771-6. https://doi.org/10.1007/s00134-007-0975-6

[19] Mani RK, Amin P, Chawla R, Divatia JV, Kapadia F, Khilnani. ,et al. Guidelines for end-of-life and palliative care in Indian intensive care units: ISCCM consensus Ethical Position Statement. Indian J Crit Care Med 2012;16(3):166-81. http://doi.org/10.4103/0972-5229.102112 
[20] Myatra SN, Salins N, Iyer S, Macaden SC, Divatia JV, Muckaden M, et al. End-of-life care policy: An integrated care plan for the dying. Indian J Crit Care Med 2014;18(9):615-35. http://doi.org/10.4103/09725229.140155

[21] Downar J, Delaney JW, Hawryluck L, Kenny L. Guidelines for the withdrawal of life-sustaining measures. Intensive Care Med 2016;42:1002-17. http://doi.org/10.1007/s00134-016-4330-7

[22] Task force on ethics of the Society of Critical Care Medicine. Consensus report on the ethics of foregoing life-sustaining treatments in the critically ill. Crit Care Med 1990;18:1435-9. http://doi.org/10.1097/00003246199012000-00026

[23] Sprung CL, Truog RD, Curtis JR, Joynt GM, Baras M, Michalsen A, et al. Seeking Worldwide Professional Consensus on the Principles of End-of-Life Care for the Critically Ill. The Consensus for Worldwide End-of-Life Practice for Patients in Intensive Care Units (WELPICUS) Study. Am J Respir Crit Care Med 2014;190(8):855-66. https://doi.org/10.1164/rccm.201403-0593CC

[24] Rocker G, Dunbar S. Withholding or withdrawal of life support: The Canadian Critical Care Society Position Paper. J Palliat Care 2000;16:S53-S62. https://doi.org/10.1177/082585970001601S10

[25] Bandrauk N, Downar J, Paunovic B. Withholding and withdrawing life-sustaining treatment: The Canadian Critical Care Society Position Paper. Can J Anaesth 2018;65:105-22. https://doi.org/10.1007/s12630-017-1002-1 [26] Vincent JL, Schetz M, De Waele JJ, de Cléty SC, Michaux I, Sottiaux T, et al. "Piece" of mind: End of life in the intensive care unit. Statement of the Belgian Society of Intensive Care Medicine. J Crit Care 2014;29:1745. https://doi.org/10.1016/j.jcrc.2013.08.025

[27] van der Heide A, van Delden JJM, Onwuteaka-Philipsen BD. End-of-Life Decisions in the Netherlands over 25 Years. N Engl J Med 2017;377:492-4. http://doi.org/10.1056/NEJMc1705630

[28] Carlet J, Thijs LG, Antonelli M, Cassell J, Cox P, Hill N, et al. Challenges in end-of-life care in the ICU. Statement of the $5^{\text {th }}$ International Consensus Conference in Critical Care: Brussels, Belgium, April 2003. Intensive Care Med 2004;30:770-84.

[29] Hinkle LJ, Bosslet GT, Torke AM. Factors associated with family satisfaction with end-of-life care in the ICU: A Systematic review. Chest 2015;147:82-93. https://doi.org/10.1378/chest.14-1098

[30] Morgan J. End-of-life care in UK critical care units - a literature review. Nurs Crit Care 2008;13:152-61. https://doi.org/10.1111/j.1478-5153.2008.00274.x

[31] Kirchhoff KT, Anumandla PR, Forth KT, Lues SN, Gilbertson-White SH. Documentation of withdrawal of life support in adult patients in the intensive care unit. Am J Crit Care 2004;13:328-34.

https://doi.org/10.4037/ajcc2004.13.4.328

[32] Lemiengre J, de Casterle BD, Van Craen K, Van Craen K, Schotsmans P, Gastmans C. Institutional ethics policies on medical end-of-life decisions: A literature review. Health policy 2007;83:131-43.

https://doi.org/10.1016/j.healthpol.2007.02.013

[33] Mast KR, Salama M, Silverman GK, Arnold RM. End-of-life content in treatment guidelines for lifelimiting diseases. J Palliat Med 2004;7:754-73. https://doi.org/10.1089/jpm.2004.7.754

[34] Steinberg A, Sprung CL. The dying patient: new Israeli legislation. Intensive Care Med 2006;32:1234-7. https://doi.org/10.1007/s00134-006-0186-6

[35] Sprung CL, Paruk F, Kisson N, Hartog CS, Lipman J, Du B, et al. The Durban World Congress Ethics Round Table Conference Report: I. Differences between withholding and withdrawing lifesustaining treatments. J Crit Care 2014;29:890-5. https://doi.org/10.1016/j.jcrc.2014.06.022

[36] Phua J, Joynt GM, Nishimura M, Deng Y, Myatra SN, Chan YH, et al. Withholding and withdrawal of lifesustaining treatments in intensive care units in Asia. JAMA Intern Med 2015;175:363-71.

https://doi.org/10.1001/jamainternmed.2014.7386

[37] Vincent JL. Forgoing life support in Western European intensive care units: The results of an ethical questionnaire. Crit Care Med 1999;27:1626-33.

[38] Sprung CL, Cohen SL, Sjokvist P, Baras M, Bulow HH, Hovilehto S, et al. End-of-life Practices in European Intensive Care Units: The Ethicus Study. JAMA 2003;290:790-7.

http://doi.org/10.1001/jama.290.6.790

[39] Vincent JL. Ethical principles in end-of-life decisions in different European countries. Swiss Med Wkly 2004; $134: 65-8$ 
[40] Sprung CL, Ricou B, Hartog CS, Maia P, Mentzelopoulos SD, Weiss M, et al. Changes in End-of-Life Pracitices in European Intensive Care Units From 1999 to 2016. JAMA 2019;322:1692-1704. https://doi.org/10.1001/jama.2019.14608

[41] van der Heide A, Deliens L, Faisst K, Nilstun T, Norup M, Paci E, et al. End-of-life decision-making in six European countries: descriptive study. Lancet 2003;362:345-50. https://doi.org/10.1016/S0140-6736(03)14019-6 [42] Schneiderman LJ, Gilmer T, Teetzel HD, Dugan DO, Blustein J, Cranford R, et al. Effects of ethics consultations on nonbeneficial life-sustaining treatments in the intensive care setting. A randomized controlled trial. JAMA 2003;290:1166-72. http://doi.org/10.1001/jama.290.9.1166

[43] Khandelwal N, Kross EK, Engelberg RA, Coe NB, Long AC, Curtis JR. Estimating the Effect of Palliative Care Interventions and Advance Care Planning on ICU Utilization: A Systematic Review. Crit Care Med 2015;43:1102-11. https://doi.org/10.1097/CCM.0000000000000852

[44] Kerckhoffs MC, Kant M, van Delden JJM, Hooft L, Kesecioglu J, van Dijk D. Selecting and evaluating decision-making strategies in the intensive care unit: A systematic review. J Crit Care. 2019;51:39-45.

https://doi.org/10.1016/j.jcrc.2019.01.029

[45] Mercadante S, Gregoretti C, Cortegiani A. Palliative care in intensive care units: why, where, what, who, when, how. BMC Anesthesiol 2018;18:106. https://doi.org/10.1186/s12871-018-0574-9 